\title{
Recent Progress on Fabrication of Zinc Oxide Nanorod-Based Field Effect Transistor Biosensors
}

\author{
(Kemajuan Terkini Fabrikasi Biosensor Berasaskan Nanorod Kesan Medan Transistor Zink Oksida)
}

\author{
Siti SHAFURA A KARIM, CHANG-Fu DEE, BURHANUdDIN YEOP MAJliS \& MOHD AMBRi MOHAMED*
}

\begin{abstract}
Zinc oxide is a unique n-type semiconducting material, owing to wide bandgap of $\sim 3.37 \mathrm{eV}$, non-toxic, bio-safe and biocompatible with high isoelectric point of $\sim 9.5$, make it as promising biomaterial to be utilized as sensing matrix in biosensor applications. In addition, $\mathrm{ZnO}$ that possess high electron affinity provide a good conduction pathway for the electrons hence result in significant electrical signal change upon detection to target biomolecules. Moreover, high surface area of $\mathrm{ZnO}$ nanorod enhance immobilization of enzymes, hence, increase the device performance. Field effect transistor (FET)-based biosensor offer simplicity in handling and label-free, has also become research topic among researchers for novel biosensor development. This review aims to explore the preparation of $\mathrm{ZnO}$ nanorod using hydrothermal method and investigate the fabrication of $\mathrm{ZnO}$ nanorod-based FET biosensor. Thus, contribute to enhance understanding towards biosensor development for health monitoring, especially based on FETs structure devices.
\end{abstract}

Keywords: Biosensor; field effect transistor; hydrothermal method; zinc oxide nanorod

ABSTRAK

Zink oksida adalah bahan semikonduktor jenis-n yang unik, disebabkan oleh ketinggian selebar $\sim 3.37$ eV, tidak toksik, selamat dan bioserasi dengan titik isoelektrik yang tinggi 9.5, menjadikan ia sebagai biobahan yang sesuai digunakan sebagai matriks penderia dalam aplikasi biosensor. Di samping itu, ZnO yang mempunyai keafinan elektron yang tinggi memberikan laluan konduksi yang baik untuk elektron dan mengakibatkan perubahan isyarat elektrik yang signifikan apabila pengesanan kepada biomolekul sasaran. Tambahan pula, kawasan permukaan ZnO nanorod yang tinggi meningkatkan immobilisasi enzim, seterusnya meningkatkan prestasi peranti. Biosensor berasaskan kesan medan transistor (FET) adalah mudah dikendalikan dan bebas label, juga menjadi topik penyelidikan dalam kalangan penyelidik untuk pembangunan biosensor yang novel. Kajian ini bertujuan untuk meneroka penyediaan $\mathrm{ZnO}$ nanorod menggunakan kaedah hidroterma dan mengkaji fabrikasi biosensor FETyang berasaskan ZnO nanorod. Sekaligus menyumbang kepada kefahaman tentang pembangunan biosensor untuk memantau kesihatan, terutamanya yang berasaskan struktur FETs.

Kata kunci: Biosensor; kaedah hidroterma; kesan medan transistor; zink oksida nanorod

\section{INTRODUCTION}

The first creation breakthrough of the biosensor development was reported in 1962 by Clark and Lyons with the discovery of detecting glucose using an enzyme electrode. Since then the understanding towards biosensor development has been exponentially expanded. However, the low efficiency of enzyme immobilization on a solid electrode is one of main challenge. Thus, nanomaterialmediated biosensor has aroused much attention as sensing matrix for biosensor development. This is due to that nanomaterials offer extremely interesting morphological, functional biocompatible, non-toxic and catalytic properties which allowed many new signal transductions and resulting in enhanced performance (Arya et al. 2012; Cheng et al. 2015; Mohammed et al. 2017). The studies on utilizing nanomaterial to fabricate and design novel devices are also keep arising due to many advantages such as miniaturization of device, enhanced performance and cost-effective (Ahmad et al. 2018; Bakar et al. 2018; Sihar et al. 2018)

Biosensor is an analytical tool that monitor the presence of specific biomolecules when biorecognition event generates the signal. Biosensor offers application particularly to detect target biomolecules or to monitor diseases at early stage in many fields such as food industry, medical and health. A typical biosensor consists of four main components: probe molecule, linker, transducer and signal processing and display component (Figure 1). A probe molecule is a biological molecule that specifically recognizes the analyte in sample. For example, DNA probe can make a specific interaction with its target complementary DNA (Galdamez et al. 2019; Kim et al. 2018). Meanwhile, a linker plays a role to immobilize probe molecule onto the device. A suitable linker ensures the signal obtained from biorecognition event transfer to the transducer. Next, a transducer used to transduce 
signal from the biorecognition event to measurable signal. A transducer which also called as a sensing matrix helps to immobilize biomolecules with retained activity and enhance signal transduction. The physico-chemical properties of the sensing matrix control the method of immobilization and the performance of the biosensors. Signal processing and display used to collect and measure the signal and display them for further analyzation.

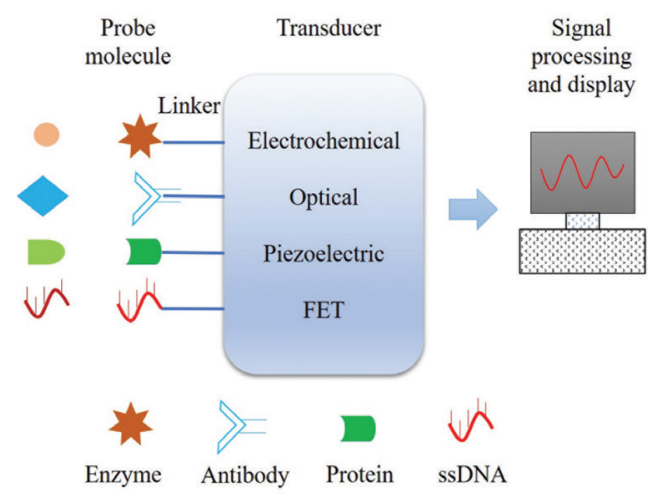

FIGURE 1. Schematic structure of typical biosensor

Zinc oxide $(\mathrm{ZnO})$ is an attractive biomaterial for its versatile properties such as semiconducting (wide bandgap of $3.37 \mathrm{eV}$ ), bio-safe and biocompatible with high isoelectric point of $\sim 9.5$. $\mathrm{ZnO}$ nanostructures can be prepared using various methods such as spin-coating (Bangbai et al. 2013; Mahmood et al.2019), hydrothermal (Shafura et al. 2018; Zhang et al. 2019), spray pyrolysis (Dedova et al. 2019), radio frequency (RF) magnetron sputtering (Baratto 2018; Ching et al. 2014), chemical vapor deposition (CVD) (Mohammed \& Hassan 2019). For instance, Saranya et al. (2017) have synthesized flower-like $\mathrm{ZnO}$ nanoflakes using hydrothermal method. Various $\mathrm{ZnO}$ nanostructures also has been obtained by hydrothermal method, as shown in Figure 2. Meanwhile, Baratto (2018) was successfully deposited $\mathrm{ZnO}$ nanorod by RF magnetron sputtering method. In addition, four kinds of $\mathrm{ZnO}$ nanostructures, nanorods, nanopencils, nanotowers and nanoneedles have been successfully deposited using CVD by manipulating the growth parameters (He et al. 2018).

Interestingly, previous studies have also reported that morphologies of $\mathrm{ZnO}$ greatly influence their material properties and device performances compared to bulk $\mathrm{ZnO}$ films (Ahmad et al. 2017; Gaiardo et al. 2016; Gao et al. 2018; Khayatian et al. 2017; Zong et al.2018). Due to their high surface-to-volume ratio and strong binding properties, $\mathrm{ZnO}$ nanostructures can achieve single-molecule detection. The high isoelectric points ( 9.5) of $\mathrm{ZnO}$ facilitates the physical immobilization of biomolecules specially to capture target biomolecules that has low isoelectric points. In addition, $\mathrm{ZnO}$ that possess high electron affinity provide a good conduction pathway for the electrons that generated from enzymatic reactions on its surface to the electrode, hence results in significant current change upon detection towards target biomolecules. At neutral $\mathrm{pH}, \mathrm{ZnO}$ possesses a positive charge, whereas enzymes with low isoelectric points (IEPs) behave like a negative charged species, which leads to an electrostatic interaction between them and caused physical binding.

Many studies on biosensors has utilizing on different morphologies of $\mathrm{ZnO}$ nanostructures, such as nanoparticles (Mahmoud et al. 2019; Medawar-Aguilar et al. 2019), nanofilms (Agarwal et al. 2019; Zhai et al.
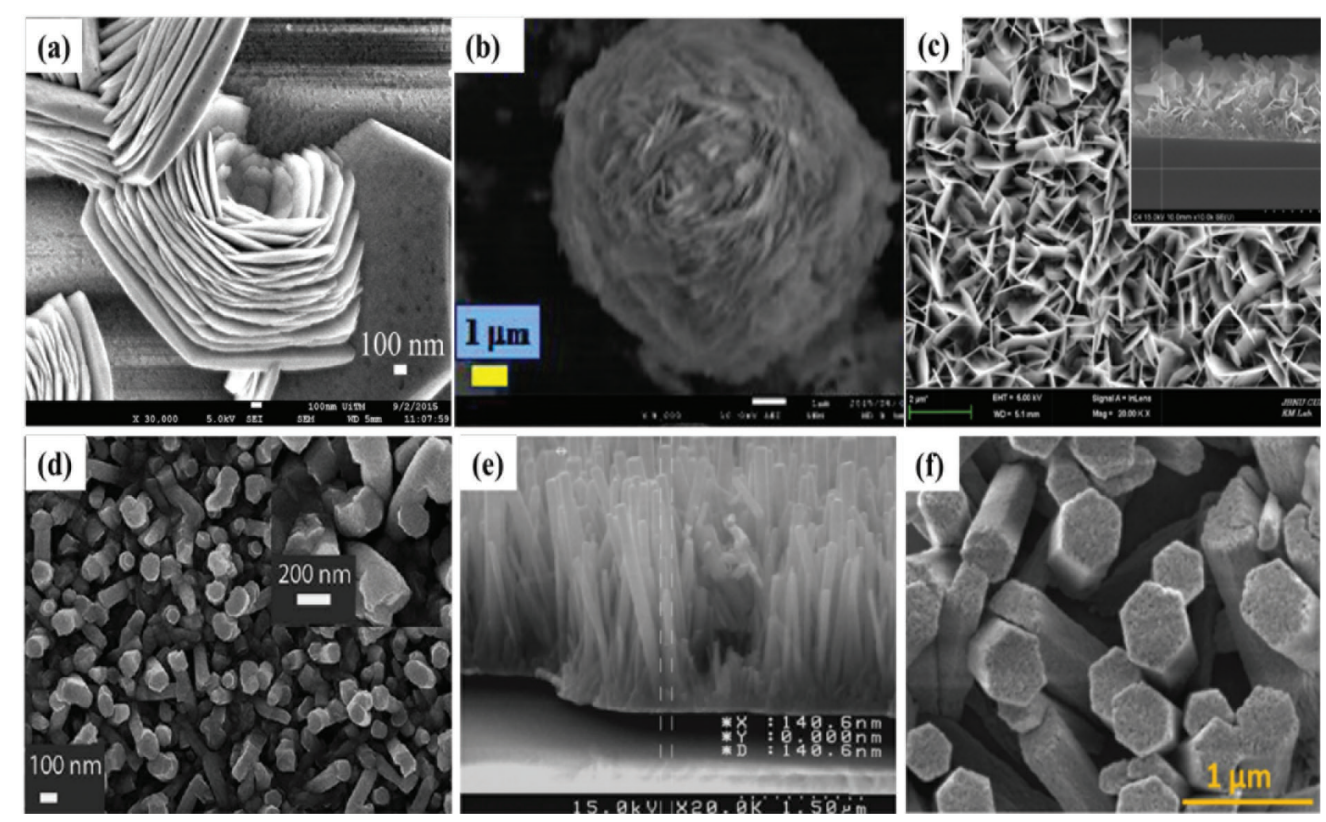

FIGURE 2. Various ZnO nanostructures obtained by hydrothermal method such as flower-like (Saranya et al. 2017; Shafura et al. 2018), nanosheets (Ahmad et al. 2015) and nanorods (Baratto et al. 2018; Fathollahzadeh et al. 2018; Mahmood et al. 2019) 
2019), nanosheets (Yue et al. 2019a), nanoflowers (Yue et al. 2019b), nanorods (Ahmad et al. 2017; Ridhuan et al. 2018; Singh et al. 2019a) and nanowires (Ditshego 2018). For instance, $\mathrm{ZnO}$ nanosheets has been utilized for biosensing matrix to detect uric acid (Ahmad et al. 2015a). The fabricated biosensor exhibited sensitivity of $129.81 \mu \mathrm{A} \mathrm{mM}^{-1} \mathrm{~cm}^{-2}$ in wide-linear range of $0.05-2.0$ $\mathrm{mM}$. Meanwhile, Ahmad et al. (2015) has reported $\mathrm{ZnO}$ nanorod-based biosensor for simultaneously detect multianalyte that are glucose, cholesterol and urea. It was found that the $\mathrm{ZnO}$ nanorods that acted as sensing matrix shown high selectivity without any interference towards those targeted bio-molecules. These attractive findings make $\mathrm{ZnO}$ as a promising sensing matrix for novel biosensor development.

\section{GROWTH OF ZINC OXIDE NANOROD USING HYDROTHERMAL METHOD}

$\mathrm{ZnO}$ has received enormous attention for device fabrication, drug delivery, biomedical applications and so on, due to many favorable properties. Directly grown vertical $\mathrm{ZnO}$ nanorods would be the most promising properties for designing biosensor devices due to its high surfaceto-volume ratio and biocompatible by nature. Among solution-based deposition methods, hydrothermal method is the most commonly used for $\mathrm{ZnO}$ nanorod synthesis (Ahmad et al. 2017; Fathollahzadeh et al. 2018; Resmini et al. 2016). This approach offers simplest preparation set-up, least energy consuming and low production cost where the $\mathrm{ZnO}$ nanorod can be grown under mild synthesis condition (such as normal pressure and low growth temperature), simple facility, good repeatability and high reliability (Gao et al. 2010; Ismail et al. 2016; Zhang et al. 2019).

$\mathrm{ZnO}$ seed layer is needed in order to grow $\mathrm{ZnO}$ nanorod/nanowire using hydrothermal method (Cheng et al. 2016; Hassanpour et al. 2017; Park et al. 2016). Usually, $\mathrm{ZnO}$ seed layer are prepared using zinc acetate dehydrate as the precursor (Greene et al. 2005; Park et al. 2016; Shafura et al. 2018). Well seed alignment significantly influences the growth of $\mathrm{ZnO}$ nanorod (Yu et al. 2017). In order to obtain well seed alignment, thermal treatment is needed at range of $150^{\circ} \mathrm{C}$ to $200^{\circ} \mathrm{C}$ for complete decomposition of zinc acetate to $\mathrm{ZnO}$. Meanwhile, annealing at temperature between $200^{\circ} \mathrm{C}$ to $500^{\circ} \mathrm{C}$ will promotes higher crystallinity and growth of seed. In addition, Greene et al. (2005) has confirmed that acetate-derived seed layer significantly improves vertical alignment of grown $\mathrm{ZnO}$ nanorod compared to unseeded and zinc nitrate-derived seed layer. Increasing the number of coating layers will reduce their grain boundaries hence providing path for electrons to move and result in increased conductivity, also shown in Figure 3 (Khan et al. 2017; Shafura et al. 2018).

In hydrothermal method, precursor play important role to determine the morphology of $\mathrm{ZnO}$. Different precursors may result in different morphology and shape which may be attributed to different reaction pathways, solubility of the precursor, and basicity of the solution which influenced the crystal nucleation and growth of $\mathrm{ZnO}$ nanorod (Yun et al. 2010). Moreover, it can be predicted that the diameter of nanorod strongly depends on diameter of seed and the length of nanorod depends on the growth time and temperature (Hassanpour et al. 2017; Jeong et al. 2011; Park et al. 2016; Yu et al. 2017). Additive of ethylene glycol (EG) assists the crystal of $\mathrm{ZnO}$ nanorod to grow homogenously attributed to its good dispersibility and glutinosity (Long et al. 2008). In addition, ammonia solution has been used to significantly control the aspect ratio and growth rate of $\mathrm{ZnO}$ nanorod (Li et al. 2019; Zhang et al. 2019). Ammonia solution can inhibit the homogeneous nucleation and promote heterogeneous nucleation in the zinc acetate-derived precursor solution. The precursor and condition used to grow $\mathrm{ZnO}$ nanorod has been summarized in Table 1. The observed $\mathrm{ZnO}$ nanorod trend grown using hydrothermal method also were presented in Figure 4.

\section{FABRICATION OF ZnO NANOROD-BASED FIELD EFFECT TRANSISTOR BIOSENSOR}

Field effect transistor (FET) has become promising platform for the fabrication of biosensors since it has drawn much attentions among scientist all over the world due to their attractive features, such as ultra-sensitive
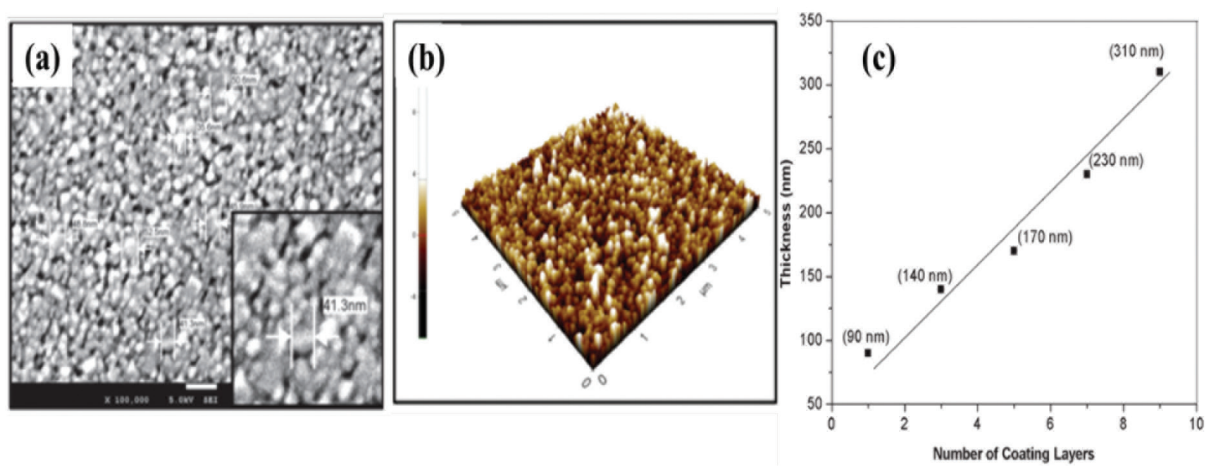

FIGURE 3. (a) The morphology and (b) AFM topography of $\mathrm{ZnO}$ seed layer prepared using acetate-derived precursor solution (c) The thicknesses obtained by increasing the number of coating layer from 1 to 9 layers (Shafura et al. 2018) 
TABLE 1. Summary of precursor and condition used to deposit $\mathrm{ZnO}$ seed layer and to grow $\mathrm{ZnO}$ nanorod using hydrothermal method

\begin{tabular}{|c|c|c|c|c|}
\hline Morphology & Precursor & Condition & Dimension & Ref. \\
\hline $\begin{array}{l}\text { Seedlayer: } \\
\text { nanoparticle }\end{array}$ & Zinc acetate $(5 \mathrm{mM})$, ethyl alcohol & $\begin{array}{l}\text { Pre-heat: } 120^{\circ} \mathrm{C} \\
\text { Anneal: } 200-400^{\circ} \mathrm{C} \\
\text { Time: } 30 \mathrm{~min}\end{array}$ & $\mathrm{D}: \sim 10 \mathrm{~nm}$ & Hassanpour et al. (2017) \\
\hline nanoparticle & $\begin{array}{l}\text { Zinc acetate dehydrate }(10 \mathrm{mM}) \text {, } \\
\text { MEA }(10 \mathrm{mM}), 2 \text {-methoxyethanol }\end{array}$ & Anneal: $400^{\circ} \mathrm{C}$ & $\mathrm{D}: \sim 5 \mathrm{~nm}$ & Cheng et al. (2016) \\
\hline nanoparticle & $\begin{array}{l}\text { Zinc acetate dehydrate }(30 \mathrm{mM}) \text {, } \\
\text { ethanol }\end{array}$ & $\begin{array}{l}\text { UVO treatment } \\
\text { Anneal: } 80-180^{\circ} \mathrm{C} \\
\text { Time: } 1 \mathrm{~h}\end{array}$ & Thickness: $38-50 \mathrm{~nm}$ & Park et al. (2016) \\
\hline nanoparticle & $\begin{array}{l}\text { Zinc acetate dehydrate }(5 \mathrm{mM}) \text {, } \\
\text { ethanol }\end{array}$ & Anneal: $350^{\circ} \mathrm{C}$ for $20 \mathrm{~min}$ & $\mathrm{D}: \sim 10 \mathrm{~nm}$ & Greene et al. (2005) \\
\hline nanoparticle & $\begin{array}{l}\text { Zinc acetate dehydrate }(0.4 \mathrm{M}) \text {, } \\
\text { MEA, 2-methoxyethanol }\end{array}$ & $\begin{array}{l}\text { Anneal: } 500^{\circ} \mathrm{C} \\
\text { for } 1 \mathrm{~h}\end{array}$ & $\begin{array}{l}\text { D: less than } 50 \mathrm{~nm} \\
\text { Thickness: } 90-310 \mathrm{~nm}\end{array}$ & Shafura et al. (2018) \\
\hline $\begin{array}{l}\text { Grown } \mathrm{ZnO} \text { : } \\
\text { nanorod }\end{array}$ & $\begin{array}{l}\text { Zinc nitrate hexahydrate }(50 \mathrm{mM}) \text {, } \\
\text { HMTA }(50 \mathrm{mM}) \text {, DI water }\end{array}$ & $\begin{array}{l}\text { Growth temp.: } 85^{\circ} \mathrm{C} \\
\text { Time: } 2 \mathrm{~h}\end{array}$ & $\begin{array}{l}\text { D: } 103 \mathrm{~nm} \\
\text { L: } 175 \mathrm{~nm}\end{array}$ & Hassanpour et al. (2017) \\
\hline nanowire & $\begin{array}{l}\text { Zinc nitrate hexahydrate }(25 \mathrm{mM}) \text {, } \\
\text { HMTA }(25 \mathrm{mM}) \text {, DI water }\end{array}$ & $\begin{array}{l}\text { Growth temp.: } 92^{\circ} \mathrm{C} \\
\text { Time: } 3 \mathrm{~h} \\
\text { Anneal: } 200^{\circ} \mathrm{C} \\
\text { Time: } 10 \mathrm{~min}\end{array}$ & $\begin{array}{l}\text { Aspect ratio: } 14 \\
\mathrm{~L}: \sim 1 \mu \mathrm{m}\end{array}$ & Park et al. (2016) \\
\hline nanowire & $\begin{array}{l}\text { Zinc nitrate hexahydrate }(2.5 \mathrm{mM}) \text {, } \\
\text { HMTA }(2.5 \mathrm{mM}) \text {, polyethyleneimine } \\
\text { (PEI, } 20 \mathrm{mg}) \text {, DI water }(3 \mathrm{~mL})\end{array}$ & $\begin{array}{l}\text { Growth temp.: } 90^{\circ} \mathrm{C} \\
\text { Time: } 1.5 \mathrm{~h}\end{array}$ & $\mathrm{~L}: \sim 1.2 \mu \mathrm{m}$ & $\begin{array}{l}\text { (Cheng et al. 2016) Cheng } \\
\text { et al. (2016) }\end{array}$ \\
\hline nanorod & $\begin{array}{l}\text { Zinc nitrate hexahydrate }(100 \mathrm{mM}) \text {, } \\
\text { HMT }(100 \mathrm{mM}) \text {, DI water }\end{array}$ & $\begin{array}{l}\text { Growth temp.: } 95^{\circ} \mathrm{C} \\
\text { Time: } 1-5 \mathrm{~h} \\
\text { Anneal: } 70^{\circ} \mathrm{C} \\
\text { Time: } 30 \mathrm{~min}\end{array}$ & $\begin{array}{l}\text { D: } 60-148 \mathrm{~nm} \\
\mathrm{~L}: \sim 0.7-3 \mu \mathrm{m}\end{array}$ & $\begin{array}{l}\text { (Jeong et al. 2011) Jeong et } \\
\text { al. (2011) }\end{array}$ \\
\hline nanorod & $\begin{array}{l}\text { Zinc nitrate hexahydrate }(30 \mathrm{mM}) \text {, } \\
\text { DI water, ammonium hydroxide } \\
(28 \text { wt. } \%)\end{array}$ & $\begin{array}{l}\text { Dope: } 5 \mathrm{mM} \text { Aluminium } \\
\text { nitrate } \\
\text { Growth temp.: } 60^{\circ} \mathrm{C} \\
\text { Time: } 6 \mathrm{~h}\end{array}$ & $\begin{array}{l}\text { Density: } 108 \text { nanorod } \\
\text { per } \mu \mathrm{m}^{2}\end{array}$ & Yun et al. (2010) \\
\hline nanowire & $\begin{array}{l}\text { Zinc nitrate hexahydrate }(25 \mathrm{mM}) \text {, } \\
\text { methenamine or diethylenetriamine } \\
(25 \mathrm{mM})\end{array}$ & $\begin{array}{l}\text { Growth temp.: } 90^{\circ} \mathrm{C} \\
\text { Time: } 1.5 \mathrm{~h}\end{array}$ & $\begin{array}{l}\text { D: } 40-80 \mathrm{~nm} \\
\mathrm{~L}: 1.5-2.0 \mu \mathrm{m}\end{array}$ & $\begin{array}{l}\text { (Greene et al. 2003) Greene } \\
\text { et al. (2003) }\end{array}$ \\
\hline nanorod & $\begin{array}{l}\text { Zinc acetate dihydrate }(40 \mathrm{mM}) \text {, } \\
\text { DI water, ammonium hydroxide } \\
(28 \mathrm{wt} . \%)\end{array}$ & $\begin{array}{l}\text { Dope: } 5 \mathrm{mM} \text { Aluminium } \\
\text { nitrate } \\
\text { Growth temp:: } 60^{\circ} \mathrm{C} \\
\text { Time: } 6 \mathrm{~h}\end{array}$ & $\begin{array}{l}\text { Density: } 186 \text { nanorod } \\
\text { per } \mu \mathrm{m}^{2}\end{array}$ & Yun et al. (2010) \\
\hline nanorod & $\begin{array}{l}\text { Zinc chloride }(50 \mathrm{mM}), \text { HMT }(50 \\
\mathrm{mM}) \text {, EG ( } 50 \text { vol. } \%) \text {, DI water }\end{array}$ & $\begin{array}{l}\text { Growth temp.: } 95^{\circ} \mathrm{C} \\
\text { Time: } 12 \mathrm{~h} \\
\text { Dry: } 80^{\circ} \mathrm{C} \\
\text { Time: } 1 \mathrm{~h}\end{array}$ & $\begin{array}{l}\mathrm{D}: \sim 2 \mu \mathrm{m} \\
\mathrm{L}: \sim 7 \mu \mathrm{m}\end{array}$ & Long et al. (2008) \\
\hline
\end{tabular}

$\mathrm{D}=$ diameter $\mathrm{L}=$ length, $\mathrm{MEA}=$ monoethanolamine, $\mathrm{HMTA}=$ hexamethylenetretramine

detection, fast measurement ability, mass production capability and low-cost manufacturing (Syu et al. 2018). Furthermore, FET based biosensor offer simplicity in handling and label-free, which mainly use electric fields to control the performance of fabricated device (Garrote et al. 2019; Singh et al. 2019).

FET based biosensors typically consist of three electrodes; source, drain and gate (Chen et al. 2017;
Cheng et al. 2015; Ditshego 2018), as shown in Figure 5 . The detection mechanism of the FET based biosensors is when the changes in electrical signal on the surface of sensing channel is detected during the target biomolecule is being captured. The output electrical signal is normally correlated to the concentration of analyte. The transfer curve determines the threshold voltage of fabricated device. In addition, the depletion layer can be controlled 


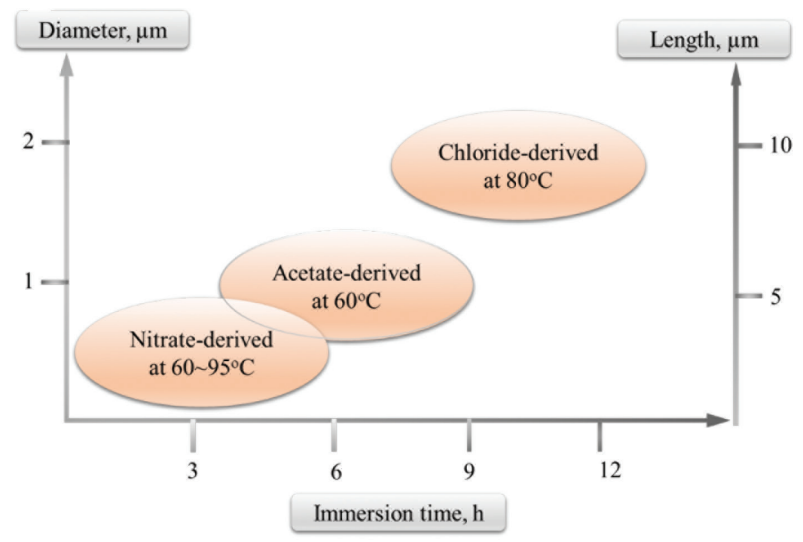

FIGURE 4. Observed $\mathrm{ZnO}$ nanorod trend grown using hydrothermal method

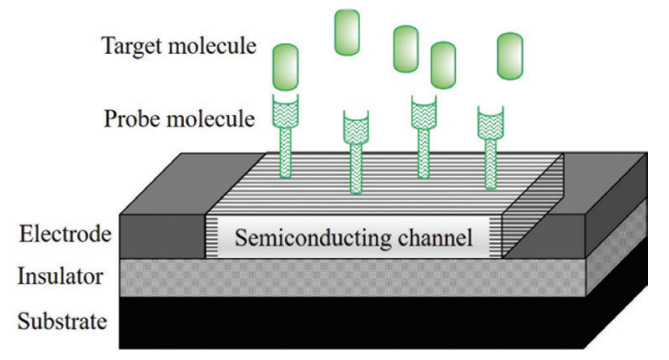

FIGURE 5. Schematic structure of a field effect transistor (FET) biosensor

by applying voltage gate, thus the sensitivity of biosensor can be controlled. High uniformity and high surfaceto-volume ratio with high immobilization efficiencies and bioactivity retainment can be achieved by utilizing nanomaterials that act as the sensing channel in FET biosensor devices (Bhat et al. 2017; Kaisti 2017). This due to that high surface-to-volume ratio of nanomaterials provide greater interconnection between the device and biomolecules and thus enhance electron transfer between them. Hence it become considerable demand for health monitoring in the near future.

Recently, $\mathrm{ZnO}$ nanostructures have aroused attention among researchers due to their potential to be utilized as a sensing matrix for biosensor applications. $\mathrm{ZnO}$ nanostructures with unique morphological, structural and electrical properties provide an effective biointerfacing platform for immobilization, biological recognition events and signal amplification. Moreover, high surface-to-volume ratio of $\mathrm{ZnO}$ nanostructures enables enhanced immobilization of enzymes onto its active surface and thus lead to more target biomolecules being recognized and captured. Moreover, $\mathrm{ZnO}$ has high chemical stability with high isoelectric point ( 9.4) which makes it an attractive sensing matrix for biosensor applications (Ahmad et al. 2017; Tripathy et al. 2018). In addition, the ease of fabrication using low cost processes (hydrothermal method) offer promising way for large scale production. Therefore, many efforts and attempts has been made to explore and enhance the performance of $\mathrm{ZnO}$ nanostructures for biosensor applications.
FET based phosphate biosensor has been developed by utilizing $\mathrm{ZnO}$ nanorod arrays as the sensing matrix, as shown in Figure 6 (Ahmad et al. 2017). Silver (Ag) as source-drain electrode were deposited using RF magnetron sputtering at $60 \mathrm{~W}$ to obtain approximately $100 \mathrm{~nm}$ of thickness. Then, $\mathrm{ZnO}$ seedlayer $(\sim 60 \mathrm{~nm})$ were sputtered between the Ag source-drain electrode. Zinc nitrate hexahydrate $(40 \mathrm{mM})$, hexamethylenetetramine (HMTA, $40 \mathrm{mM}$ ) and deionized water were used to prepare $\mathrm{ZnO}$ solution. Then, $\mathrm{ZnO}$ nanorod arrays were grown on $\mathrm{SiO}_{2} / \mathrm{Si}$ substrates using hydrothermal method at $85^{\circ} \mathrm{C}$ for $4 \mathrm{~h}$. They obtained $\mathrm{ZnO}$ nanorod with length of approximately $1.2 \mu \mathrm{m}$ and diameter of approximately 80-90 $\mathrm{nm}$. The ZnO nanorod based FET biosensor exhibited higher current response compared to bare FET biosensor. This were due to vertically grown nanorod arrays has exhibited higher surface area which enhanced the immobilization of pyruvate oxidase $(\mathrm{PyO})$ to detect the presence of phosphate. As a result, higher specificity and sensitivity $\left(80.57 \mu \mathrm{A} \mathrm{mM}{ }^{-1} \mathrm{~cm}^{-2}\right)$ were obtained to detect phosphate in range of $0.1 \mu \mathrm{M}-7.0 \mathrm{mM}$.

Continuous glucose monitoring is crucial for diabetic patients to prevent diabetes complications. Zong et al. (2018) has successfully fabricated glucose FET biosensor for continuously detect glucose by utilizing $\mathrm{ZnO}$ nanorod as the sensing matrix to transduce glucose concentrations to measurable current signal, also can be observed in Figure 7. The $\mathrm{ZnO}$ nanorod were grown between $\mathrm{Cr} / \mathrm{Au}$ source-drain electrode $(100 \mathrm{~nm})$ using electric-field assisted hydrothermal method at $75^{\circ} \mathrm{C}$ for 

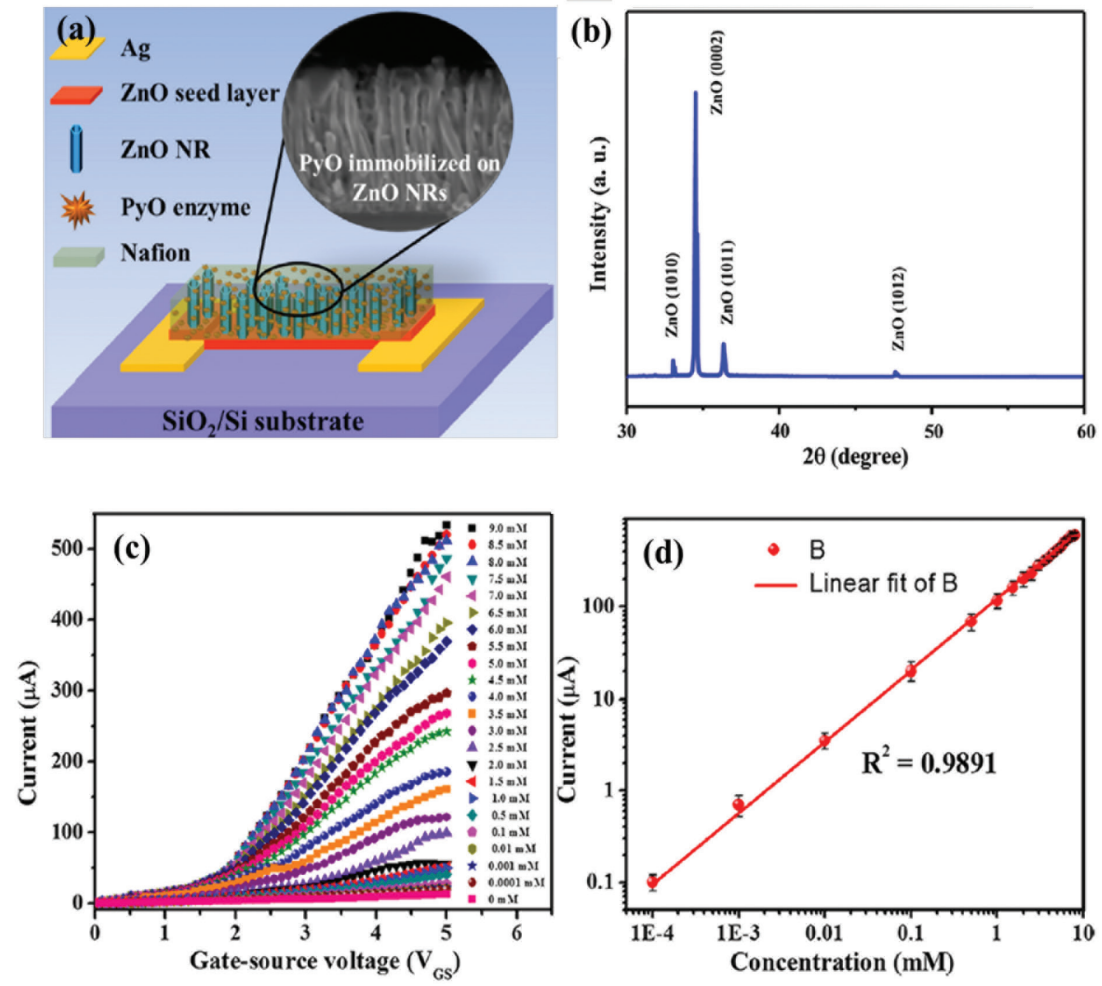

FIGURE 6. (a) Schematic view of ZnO-based FET biosensor and cross-sectional image of ZnO nanorod arrays (inset) (b) XRD pattern of $\mathrm{ZnO}$ nanorod grown on $\mathrm{SiO}_{2} / \mathrm{Si}$ substrate (c) transfer curve of the device at increasing phosphate concentrations from $0.1 \mu \mathrm{M}$ to $9.0 \mathrm{mM}$ in 0.02 M HEPES buffer (pH7.0) and (d) the device corresponding calibration curve (Ahmad et al. 2017)
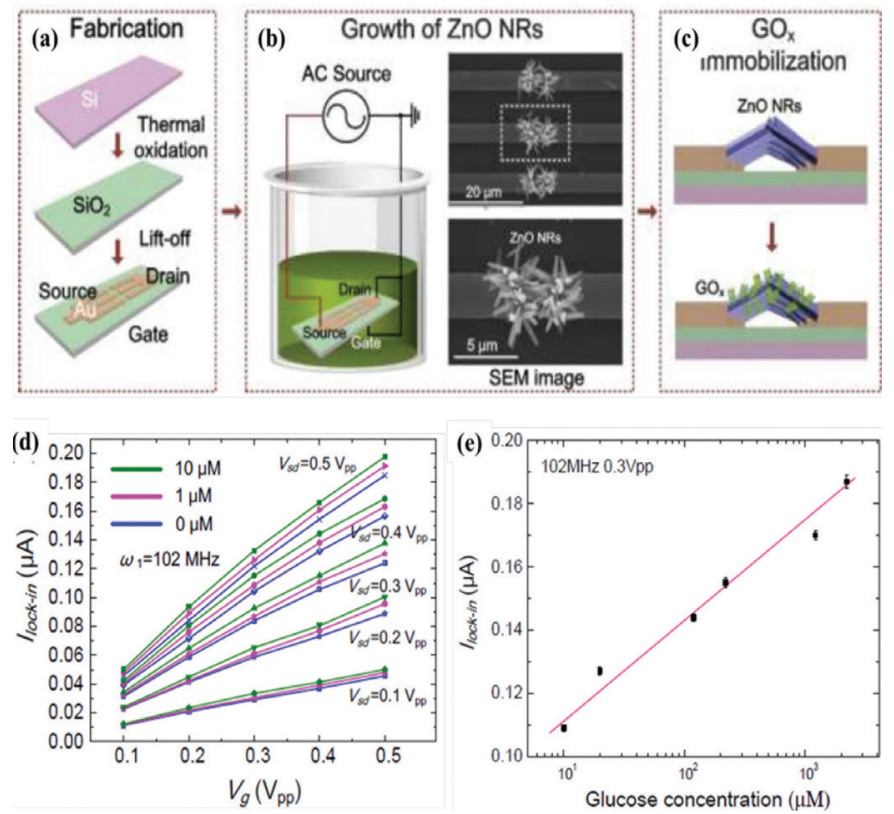

FIGURE 7. (a) Fabrication of source-drain electrodes of FET biosensor, (b) electric field-assisted hydrothermal method used to grow $\mathrm{ZnO}$ nanorod, (c) schematic view of $\mathrm{ZnO}$ nanorod based FET biosensor, (d) current-voltage

(I-V) measurement at glucose concentrations from 0 to $10 \mu \mathrm{M}$ by varying the source-drain voltage $\left(\mathrm{V}_{\mathrm{sd}}\right)$ and (e) the device corresponding calibration curve (Zhong et al. 2018)

$5 \mathrm{~h}$. They prepared equimolar aqueous solution $(15 \mathrm{mM})$ using zinc nitrate hexahydrate and HMTA. Then, the $\mathrm{ZnO}$ nanorod were immobilized using glucose oxidase (GOx) for glucose detection. The $\mathrm{ZnO}$ nanorod has diameter of $\sim 300-500 \mathrm{~nm}$ and length of $\sim 1-2 \mu \mathrm{m}$. High surface area of nanorod enhanced immobilization of GOx and resulted 
higher sensitivity of $1.6 \mathrm{~mA} \mu \mathrm{M}^{-1} \mathrm{~cm}^{-2}$ towards $1 \mu \mathrm{M}$ of glucose concentration. In addition, Fathollahzadeh et al. (2018) has demonstrated $\mathrm{ZnO}$ nanorod-based liquid-gated FET biosensor to specifically detect glucose, as shown in Figure 8. Ti/ Au (100 nm/200 nm) source-drain electrode was used for FET device fabrication. Meanwhile, $\mathrm{ZnO}$ nanorod were grown using hydrothermal method at $90^{\circ} \mathrm{C}$ for $3 \mathrm{~h}$. The equimolar aqueous solution $(10 \mathrm{mM})$ of zinc nitrate hexahydrate and HMTA were used to grown $\mathrm{ZnO}$ nanorod with diameter and length of approximately 150 $\mathrm{nm}$ and $1 \mu \mathrm{m}$, respectively. The device has detection limit up to $3.8 \mu \mathrm{M}$ and showed fast response time of $10 \mathrm{~s}$.

Monitoring cholesterol is important to manage and plan a treatment for many diseases such as coronary heart diseases, stroke, hypertension and arteriosclerosis etc. High sensitivity, long-term stability and high repeatability of cholesterol biosensor is needed. Therefore, Ahmad et al. (2013) has developed high performance $\mathrm{ZnO}$ nanorodbased FET biosensor to specifically detect cholesterol. Hydrothermal method was used to grow highly crystalline (0002) plane of $\mathrm{ZnO}$ nanorod. $\mathrm{ZnO}$ that owing to high surface area has enhanced the immobilization of cholesterol oxidase $(\mathrm{ChOx})$. The device exhibited sensitivity of $10 \mathrm{~mA} \mathrm{mM}^{-1} \mathrm{~cm}^{-2}$ for wide-linear range of cholesterol concentration (0.001-45 mM). Interestingly, by utilizing $\mathrm{ZnO}$ nanorod as sensing matrix has discover its properties to simultaneously detect multi-analyte as has been discovered by Ahmad et al. (2015b) as shown in Figure 9. The device exhibited high selectivity towards detection of glucose, cholesterol and urea. The comparative results from the previous works has been summarized in Table 2 .

\section{CONCLUSION}

Nanotechnology offers advantageous approaches for miniaturization and novel device development. Field effect transistor-based biosensor is one of promising devices for biosensor development due to easy in handling and label-free with high sensitivity towards detection of target biomolecules. By utilizing zinc oxide $(\mathrm{ZnO})$ nanorod as the sensing matrix, enhanced performance of FET based biosensor can be obtained. High surface-to-volume ratio, high electron affinity and high electron mobility of $\mathrm{ZnO}$ nanorod attribute to enhance the device performance. Among solution-based approach, hydrothermal method is the most favorable method due to its many advantages such as simple, least energy consuming and high repeatability. However, it is still a challenge to obtain tunable $\mathrm{ZnO}$ nanorod using hydrothermal method. Thus, there is a need to further studies on control the growth of $\mathrm{ZnO}$ nanorod using hydrothermal method in development of novel FET based biosensor. (a)

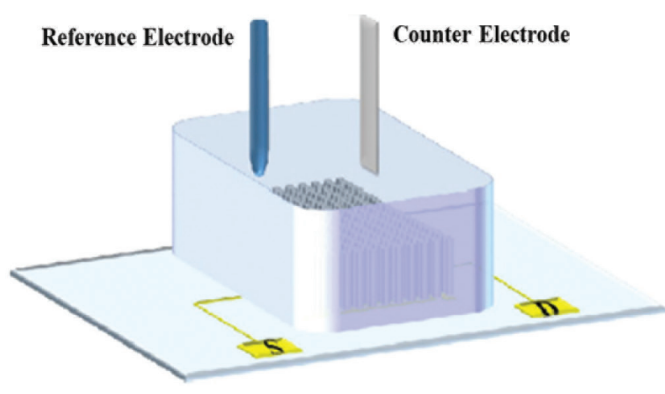

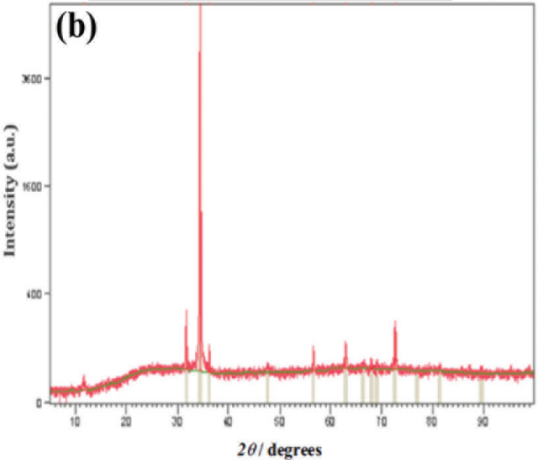

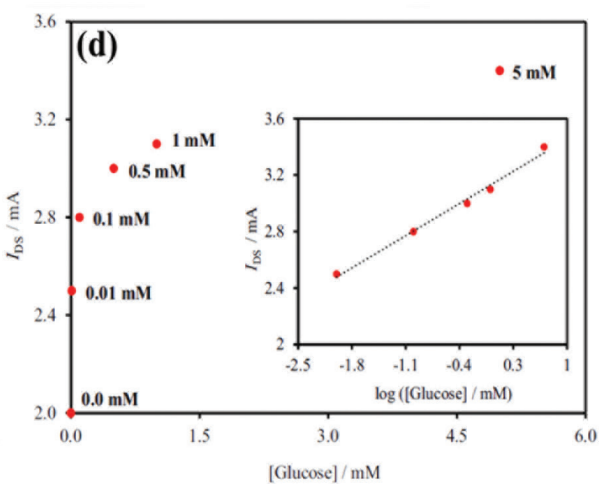

FIGURE 8. (a) Schematic view of glass-based liquid-gated FET biosensor (b) XRD pattern of grown ZnO nanorod (c) transfer curve of GOx/ZnO nanorods based FET biosensor in $0.01 \mathrm{M}$ PBS (pH7.4) at $0.1 \mathrm{mM}$ glucose and (d) their corresponding calibration curve for glucose (Fathollahzadeh et al. 2018) 
(a)

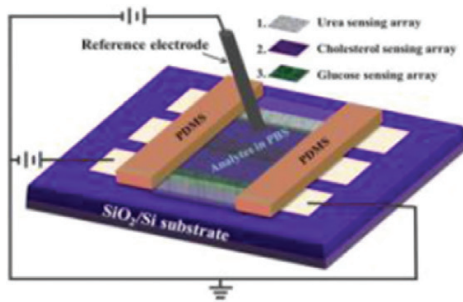

(c)

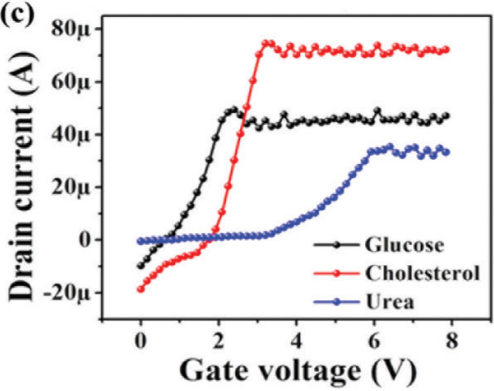

(b)
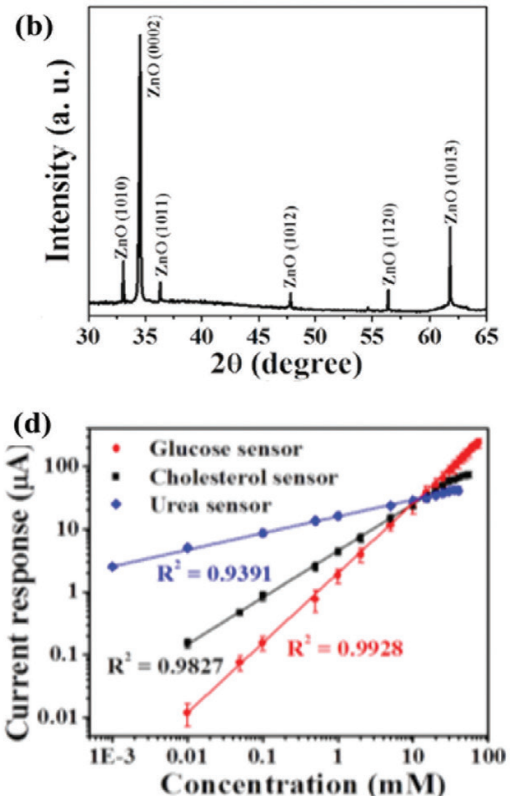

FIGURE 9. (a) Schematic view of FET device measurement to simultaneously detect multi-analyte (b) XRD pattern of deposited $\mathrm{ZnO}$ nanorod using hydrothermal method (c) transfer curve of fabricated device and (d) the corresponding calibration curve for glucose, cholesterol and urea detection, respectively (Ahmad et al. 2015b)

TABLE 2. Comparative results of $\mathrm{ZnO}$ nanorod-based FET biosensors

\begin{tabular}{|c|c|c|c|c|c|}
\hline Morphology & Electrode & Enzyme & Target & Sensitivity & Ref. \\
\hline $\begin{array}{l}\text { D: } \sim 80-90 \mathrm{~nm} \\
\mathrm{~L}: \sim 1.2 \mu \mathrm{m}\end{array}$ & $\begin{array}{l}\mathrm{Ag} \\
(100 \mathrm{~nm})\end{array}$ & $\mathrm{PyO}$ & phosphate & $80.57 \mu \mathrm{A} \mathrm{mM}^{-1} \mathrm{~cm}^{-2}$ & Ahmad et al. (2017) \\
\hline $\begin{array}{l}\mathrm{D}: \sim 300-500 \mathrm{~nm} \\
\mathrm{~L}: \sim 1-2 \mu \mathrm{m}\end{array}$ & $\mathrm{Cr} / \mathrm{Au}(100 \mathrm{~nm})$ & GOx & glucose & $1.6 \mathrm{~mA} \mu \mathrm{M}^{-1} \mathrm{~cm}^{-2}$ & Zong et al. (2018) \\
\hline $\begin{array}{l}\mathrm{D}: \sim 150 \mathrm{~nm} \\
\mathrm{~L}: \sim 1 \mu \mathrm{m}\end{array}$ & $\begin{array}{l}\mathrm{Ti}(100 \mathrm{~nm}) / \\
\mathrm{Au}(200 \mathrm{~nm})\end{array}$ & GOx & glucose & Not reported & Fathollahzadeh et al. (2018) \\
\hline $\begin{array}{l}\mathrm{D}: \sim 100 \mathrm{~nm} \\
\mathrm{~L}: \sim 2 \mu \mathrm{m}\end{array}$ & $\mathrm{Ag} / \mathrm{AgCl}$ & $\mathrm{ChOx}$ & cholesterol & $10 \mathrm{~mA} \mathrm{mM}^{-1} \mathrm{~cm}^{-2}$ & Ahmad et al. (2013) \\
\hline $\begin{array}{l}\mathrm{D}: \sim 50 \mathrm{~nm} \\
\mathrm{~L}: \sim 1 \mu \mathrm{m}\end{array}$ & $\mathrm{Ag}$ & $\begin{array}{l}\mathrm{GOx} \\
\mathrm{ChOx} \\
\text { urease }\end{array}$ & $\begin{array}{l}\text { glucose } \\
\text { cholesterol } \\
\text { urea }\end{array}$ & $\begin{array}{l}32.27 \mu \mathrm{A} \mathrm{mM}^{-1} \mathrm{~cm}^{-2} \\
17.10 \mu \mathrm{AmM}^{-1} \mathrm{~cm}^{-2} \\
14.23 \mu \mathrm{AmM}^{-1} \mathrm{~cm}^{-2}\end{array}$ & Ahmad et al. (2015b) \\
\hline
\end{tabular}

\section{ACKNOWLEDGEMENTS}

This work is supported in part by research grant LRGS/2015/ UKM-UKM/NANOMITE/04/01 from the Ministry of Education Malaysia and grant number GUP-2018-082 from Universiti Kebangsaan Malaysia.

\section{REFERENCES}

Agarwal, D.K., Kandpal, M. \& Surya, S.G. 2019. Characterization and detection of cardiac troponin-t protein by using 'aptamer' mediated biofunctionalization of $\mathrm{ZnO}$ thin-film transistor. Applied Surface Science 466: 874-881.

Ahmad, R., Mahmoudi, T.,Ahn, M.S.\& Hahn, Y.B. 2018. Recent advances in nanowires-based field-effect transistors for biological sensor applications. Biosensors and Bioelectronics 100: 312-325.

Ahmad, R., Ahn, M.S. \& Hahn, Y.B. 2017. ZnO nanorods array based field-effect transistor biosensor for phosphate detection. Journal of Colloid and Interface Science 498: 292-297.
Ahmad, R., Tripathy, N., Jang, N.K., Khang, G. \& Hahn, Y.B. 2015a. Fabrication of highly sensitive uric acid biosensor based on directly grown $\mathrm{ZnO}$ nanosheets on electrode surface. Sensors and Actuators B: Chemical 206: 146-151.

Ahmad, R., Tripathy, N., Park, J.H. \& Hahn, Y.B. 2015b. A comprehensive biosensor integrated with a $\mathrm{ZnO}$ nanorod fet array for selective detection of glucose, cholesterol and urea. Chemical Communications 51(60): 11968-11971.

Ahmad, R., Tripathy, N. \& Hahn, Y.B. 2013. High-performance cholesterol sensor based on the solution-gated field effect transistor fabricated with $\mathrm{ZnO}$ nanorods. Biosens Bioelectron 45: 281-286.

Arya, S.K., Saha, S., Ramirez-Vick, J.E., Gupta, V., Bhansali, S. \& Singh, S.P. 2012. Recent advances in $\mathrm{ZnO}$ nanostructures and thin films for biosensor applications: Review. Analytica Chimica Acta 737: 1-21.

Bakar, E.A., Mohamed, M.A., Ooi, P.C., Wee, M.F.M.R., Dee, C.F. \& Majlis, B.Y. 2018. Fabrication of indium-tin-oxide free, all-solution-processed flexible nanogenerator device 
using nanocomposite of barium titanate and graphene quantum dots in polyvinylidene fluoride polymer matrix. Organic Electronics 61: 289-295.

Bangbai, C., Chongsri, K., Pecharapa, W. \& Techidheera, W. 2013. Effect of Al and $\mathrm{N}$ doping on structural and optical properties of sol-gel derived $\mathrm{ZnO}$ thin films. Sains Malaysiana 42(2): 239-246.

Baratto, C. 2018. Growth and properties of $\mathrm{ZnO}$ nanorods by Rf-sputtering for detection of toxic gases. RSC Advances 8(56): 32038-32043.

Bhat, S.S., Qurashi,A. \& Khanday, F.A. 2017.Zno nanostructures based biosensors for cancer and infectious disease applications: Perspectives, prospects and promises. $\operatorname{Tr} A C$ Trends in Analytical Chemistry 86: 1-13.

Chen, Y., Ren, R., Pu, H., Guo, X., Chang, J., Zhou, G., Mao, S., Kron, M. \& Chen, J. 2017. Field-effect transistor biosensor for rapid detection of ebola antigen. Scientific Reports 7(1): 10974.

Cheng, J.J., Nicaise, S.M., Berggren, K.K. \& Gradečak, S. 2016. Dimensional tailoring of hydrothermally grown zinc oxide nanowire arrays. Nano Letters 16(1): 753-759.

Cheng, S., Hideshima, S., Kuroiwa, S., Nakanishi, T. \& Osaka, T. 2015. Label-free detection of tumor markers using field effect transistor (Fet)-based biosensors for lung cancer diagnosis. Sensors and Actuators B: Chemical 212: 329-334.

Ching, C., Ooi, P., Ng, S., Hassan,Z., Hassan, H. \& Abdullah, M. 2014. Structural properties of zinc oxide thin films deposited on various substrates. Sains Malaysiana 43(6): 923-927.

Clark, J.L.C. \& Lyons, C. 1962. Electrode systems for continuous monitoring in cardiovascular surgery. Annals of the New York Academy of Sciences 102(1): 29-45.

Dedova, T., Acik, I.O., Polivtseva, S., Krunks, M., Gromyko, I., Tõnsuaadu, K. \& Mere, A. 2019. Influence of solution composition on sprayed Zno nanorods properties and formation process: Thermoanalytical study of the precursors. Ceramics International 45(2): 2887-2892.

Ditshego, N.M.J. 2018. Highly sensitive ZnO NWFET biosensor fabricated using top-down processes. Journal of Nano Research 55: 66-74.

Fathollahzadeh, M., Hosseini, M., Norouzi, M., Ebrahimi, A., Fathipour, M., Kolahdouz, M. \& Haghighi, B. 2018. Immobilization of glucose oxidase on $\mathrm{ZnO}$ nanorods decorated electrolyte-gated field effect transistor for glucose detection. Journal of Solid State Electrochemistry 22(1): 61-67.

Gaiardo, A., Fabbri, B., Giberti,A., Guidi, V., Bellutti, P., Malagù, C., Valt, M., Pepponi, G., Gherardi, S., Zonta, G., Martucci, A., Sturaro, M. \& Landini, N. 2016. Zno and Au/Zno thin films: Room-temperature chemoresistive properties for gas sensing applications. Sensors and Actuators B: Chemical 237: 1085-1094.

Galdamez, A., Serrano, A., Santana, G., Arjona, N., Arriaga, L.G., Tapia Ramirez, J., Oza, G. \& Dutt, A. 2019. DNA probe functionalization on different morphologies of $\mathrm{Zno} /$ Au nanowire for bio-sensing applications. Materials Letters 235: 250-253

Gao, S.Y., Li, H.D., Yuan, J.J., Li, Y.A., Yang, X.X. \& Liu, J.W. 2010. ZnO nanorods/plates on Si substrate grown by lowtemperature hydrothermal reaction. Applied Surface Science 256(9): 2781-2785.

Gao, Z., Zhang, J., Li, J., Xue, X., Zhao, L., Lu, L., Deng, J., Wan, P., Cui, B. \& Zou, D. 2018. Improving the fabrication uniformity of $\mathrm{ZnO}$ nanowire UV sensor by step-corner growth mode. Ceramics International 44(11): 11972-11982.
Garrote, B.L., Fernandes, F.C.B., Cilli, E.M. \& Bueno,P.R. 2019. Field effect in molecule-gated switches and the role of targetto-receptor size ratio in biosensor sensitivity. Biosensors and Bioelectronics 127: 215-220.

Greene, L.E., Law, M., Goldberger, J., Kim, F., Johnson, J.C., Zhang, Y., Saykally, R.J. \& Yang, P. 2003. Low-temperature wafer-scale production of $\mathrm{ZnO}$ nanowire arrays. Angewandte Chemie International Edition 42(26): 3031-3034.

Greene, L.E., Law, M., Tan, D.H., Montano, M., Goldberger, J., Somorjai, G. \& Yang, P. 2005. General route to vertical $\mathrm{ZnO}$ nanowire arrays using textured $\mathrm{ZnO}$ seeds. Nano Letters 5(7): 1231-1236.

Hassanpour, A., Bogdan, N., Capobianco, J.A. \& Bianucci, P. 2017. Hydrothermal selective growth of low aspect ratio isolated $\mathrm{ZnO}$ nanorods. Materials \& Design 119: 464-469.

He, J., Zheng, X., Hong, X., Wang, W., Cao, Y., Chen, T., Kong, L., Wu, Y., Wu, Z. \& Kang, J. 2018. Enhanced field emission of $\mathrm{ZnO}$ nanowire arrays by the control of their structures. Materials Letters 216: 182-184.

Ismail, A.S., Mamat, M.H., Md. Sin, N.D., Malek, M.F., Zoolfakar, A.S., Suriani, A.B., Mohamed, A., Ahmad, M.K. \& Rusop, M. 2016. Fabrication of hierarchical Sn-doped ZnO nanorod arrays through sonicated sol-gel immersion for room temperature, resistive-type humidity sensor applications. Ceramics International 42(8): 9785-9795.

Jeong, Y.I., Shin, C.M., Heo, J.H., Ryu, H., Lee, W.J., Chang, J.H., Son, C.S. \& Yun, J. 2011. Effects of growth duration on the structural and optical properties of $\mathrm{ZnO}$ nanorods grown on seed-layer $\mathrm{ZnO} /$ polyethylene terephthalate substrates. Applied Surface Science 257(24): 10358-10362.

Kaisti, M. 2017. Detection principles of biological and chemical fet sensors. Biosensors and Bioelectronics 98: 437-448.

Khan, M.I., Bhatti, K.A., Qindeel, R., Alonizan, N. \& Althobaiti, H.S. 2017. Characterizations of multilayer $\mathrm{ZnO}$ thin films deposited by sol-gel spin coating technique. Results in Physics 7: 651-655.

Khayatian, A., Asgari, V., Ramazani, A., Akhtarianfar, S.F., Kashi, M.A. \& Safa, S. 2017. Diameter-controlled synthesis of $\mathrm{ZnO}$ nanorods on $\mathrm{Fe}$-doped $\mathrm{ZnO}$ seed layer and enhanced photodetection performance. Materials Research Bulletin 94: 77-84.

Kim, Y.G., Tak, Y.J., Kim, H.J., Kim, W.G., Yoo, H. \& Kim, H.J. 2018. Facile fabrication of wire-type indium gallium zinc oxide thin-film transistors applicable to ultrasensitive flexible sensors. Scientific Reports 8(1): 5546.

Li, D., Li, Y., Zhang, Y. \& Chang, F. 2019. Facile synthesis of three-dimensional Zno hierarchical microspheres composed of well-ordered nanorods by hydrothermal method. Results in Physics 12: 953-958.

Long, T., Yin, S., Takabatake, K., Zhnag, P. \& Sato, T. 2008. Synthesis and characterization of $\mathrm{ZnO}$ nanorods and nanodisks from zinc chloride aqueous solution. Nanoscale Research Letters 4(3): 247.

Mahmood, K., Hameed, M., Rehman, F., Khalid, A., Imran, M \& Mehran, M.T. 2019. A multifunctional blade-coated $\mathrm{ZnO}$ seed layer for high-efficiency perovskite solar cells. Applied Physics A 125(2): 83.

Mahmoud, A., Echabaane, M., Omri, K., El Mir, L. \& Ben Chaabane, R. 2019. Development of an impedimetric non enzymatic sensor based on $\mathrm{ZnO}$ and $\mathrm{Cu}$ doped $\mathrm{ZnO}$ nanoparticles for the detection of glucose. Journal of Alloys and Compounds 786: 960-968.

Medawar-Aguilar, V., Jofre, C.F., Fernández-Baldo, M.A., Alonso, A., Angel, S., Raba, J., Pereira, S.V. \& Messina, G.A. 
2019. Serological diagnosis of toxoplasmosis disease using a fluorescent immunosensor with chitosan-ZnO-nanoparticles. Analytical Biochemistry 564-565: 116-122.

Mohammed, A.J. \& Hassan, T.A.A. 2019. A new piezoamperometric sensing method based on comb-like nanostructured zinc oxide thin films for the efficient detection of Na2So4. Energy Procedia 157: 1191-1201.

Mohammed, A.M., Ibraheem, I.J., Obaid, A.S. \& Bououdina, M. 2017. Nanostructured ZnO-based biosensor: DNA immobilization and hybridization. Sensing and Bio-Sensing Research 15: 46-52.

Park, J.S., Mahmud, I., Shin, H.J., Park, M.K., Ranjkesh, A., Lee, D.K. \& Kim, H.R. 2016. Effect of surface energy and seed layer annealing temperature on Zno seed layer formation and $\mathrm{ZnO}$ nanowire growth. Applied Surface Science 362: 132-139.

Resmini, A., Anselmi-Tamburini, U., Emamjomeh, S.M., Paolucci, V., Tredici, I.G. \& Cantalini, C. 2016. The influence of the absolute surface area on the No2 and $\mathrm{H} 2$ gas responses of $\mathrm{ZnO}$ nanorods prepared by hydrothermal growth. Thin Solid Films 618: 246-252.

Ridhuan, N.S.,Abdul Razak, K.\& Lockman,Z. 2018. Fabrication and characterization of glucose biosensors by using hydrothermally grown Zno nanorods. Scientific Reports 8(1): 13722.

Saranya, P.E. \& Selladurai, S. 2017. Facile synthesis of selfassembled flower-like mesoporous zinc oxide nanoflakes for energy applications. International Journal of Nanoscience 17(01n02): 1760002.

Shafura, A.K., Saurdi, I., Sin, N.D.M., Noor, U.M., Mamat, M.H., Alrokayan, S.A.H., Khan, H.A. \& Rusop, M. 2018. Structural and electrical properties of nanostructured $\mathrm{ZnO}$. AIP Conference Proceedings 1963(1): 020052.

Shafura,A.K., Saurdi, I., Sin, N.D.M., Noor, U.M., Mamat, M.H., Alrokayan, S.a.H., Khan, H.A. \& Rusop, M. 2018. Structural properties of Zno nano-template layer by spin coating method. AIP Conference Proceedings 1963(1): 020034.

Sihar, N., Tiong, T.Y., Dee, C.F., Ooi, P.C., Hamzah, A.A., Mohamed, M.A. \& Majlis, B.Y. 2018. Ultraviolet lightassisted copper oxide nanowires hydrogen gas sensor. Nanoscale Research Letters 13(1): 150

Singh, A.C., Asif, M.H., Bacher, G., Danielsson, B., Willander, M. \& Bhand, S. 2019a. Nanoimmunosensor based on $\mathrm{ZnO}$ nanorods for ultrasensitive detection of $17 \beta$-estradiol. Biosensors and Bioelectronics 126: 15-22.

Singh, N.K., Thungon, P.D., Estrela, P. \& Goswami, P. 2019b. Development of an aptamer-based field effect transistor biosensor for quantitative detection of plasmodium falciparum glutamate dehydrogenase in serum samples. Biosensors and Bioelectronics 123: 30-35.
Syu, Y.C., Hsu, W.E. \& Lin, C.T. 2018. Review-Field-effect transistor biosensing: Devices and clinical applications. ECS Journal of Solid State Science and Technology 7(7): Q3196-Q3207.

Tripathy, N. \& Kim, D.H. 2018. Metal oxide modified ZnO nanomaterials for biosensor applications. Nano Convergence 5(1): 27-37.

Yu, Z., Li, H., Qiu, Y., Yang, X., Zhang, W., Xu, N., Sun, J. \& Wu, J. 2017. Size-controllable growth of Zno nanorods on Si substrate. Superlattices and Microstructures 101: 469-479.

Yue, H.Y., Song, S.S., Guo, X.R., Huang, S., Gao, X., Wang, Z., Wang, W.Q., Zhang, H.J. \& Wu, P.F. 2019a. ThreeDimensional $\mathrm{ZnO}$ nanosheet spheres/graphene foam for electrochemical determination of levodopa in the presence of uric acid. Journal of Electroanalytical Chemistry 838: 142-147.

Yue, H.Y., Wu, P.F., Huang, S., Gao, X., Wang, Z., Wang, W.Q., Zhang, H.J., Song, S.S. \& Guo, X.R. 2019b. Electrochemical determination of levodopa in the presence of uric acid using $\mathrm{ZnO}$ nanoflowers-reduced graphene oxide. Journal of Materials Science: Materials in Electronics 30(4): 39843993.

Yun, S., Lee, J., Yang, J. \& Lim, S. 2010. Hydrothermal synthesis of Al-doped $\mathrm{ZnO}$ nanorod arrays on Si substrate. Physica B: Condensed Matter 405(1): 413-419.

Zhai, Y., Liu, D., Jiang, Y., Chen, X., Shao, L., Li, J., Sheng, K., Zhang, X. \& Song, H. 2019. Near-infrared-light-triggered photoelectrochemical biosensor for detection of alphafetoprotein based on upconversion nanophosphors. Sensors and Actuators B: Chemical 286: 468-475.

Zhang, Z., Chen, Y. \& Guo, J. 2019. ZnO nanorods patternedtextile using a novel hydrothermal method for sandwich structured-piezoelectric nanogenerator for human energy harvesting. Physica E: Low-Dimensional Systems and Nanostructures 105: 212-218.

Zong, X. \& Zhu, R. 2018. ZnO nanorod-based fet biosensor for continuous glucose monitoring. Sensors and Actuators B: Chemical 255: 2448-2453.

Institute of Microengineering and Nanoelectronics (IMEN)

Universiti Kebangsaan Malaysia

43600 UKM Bangi, Selangor Darul Ehsan

Malaysia

*Corresponding author; email: ambri@ukm.edu.my

Received: 20 February 2019

Accepted: 19 March 2019 